\title{
Regulation of Extracellular UTP-Activated Cl- Current by P2Y-PLC-PKC Signaling and ATP Hydrolysis in Mouse Ventricular Myocytes
}

\author{
Shintaro YAMAMOTO, Kunihiko ICHISHIMA, and Tsuguhisa EHARA \\ Department of Physiology, Saga University Faculty of Medicine, Saga, 849-8501 Japan
}

\begin{abstract}
The intracellular signaling pathways responsible for extracellualr uridine-5'-triphosphate (UTP $)$-induced chloride $\left(\mathrm{Cl}^{-}\right)$currents $\left(I_{\text {CI.UTP }}\right)$ were studied in mouse ventricular myocytes with the whole-cell clamp technique. UTP 0 (0.1 to $100 \mu \mathrm{M})$ activated a whole-cell current that showed a time-independent activation, a linear current-voltage relationship in symmetrical $\mathrm{Cl}^{-}$solutions, an anion selectivity of $\mathrm{Cl}^{-}>$iodide > aspartate, and an inhibition by a thiazolidinone-derived specific inhibitor (CFTR $\left._{\text {inh }}-172,10 \mu \mathrm{M}\right)$ of cystic fibrosis transmembrane conductance regulator (CFTR), but not by a disulfonic stilbene derivative (DIDS, $100 \mu \mathrm{M}$ ), these properties matching those of CFTR $\mathrm{Cl}^{-}$channels. The potency order of nucleotides for an activation of the $\mathrm{Cl}^{-}$current was UTP $=$ATP $>$uridine-5'-diphosphate $(\mathrm{UDP})=$ ADP. Suramin $(100 \mu \mathrm{M})$, a P2Y receptor antagonist, strongly inhibited the UTP $\mathrm{P}_{0}$-activation of the $\mathrm{Cl}^{-}$current, where-
\end{abstract}

as pyridoxalphosphate-6-azophenyl-2',4'-disulfonic acid (PPADS, $100 \mu \mathrm{M}$ ), another P2Y receptor antagonist, induced little inhibition of $I_{\text {CI.UTP }}$. The activation of $I_{\text {CI.UTP }}$ was sensitive to protein kinase $C$ (PKC) inhibitor, phospholipase $C$ (PLC) inhibitor, intracellular GDP $\beta S$ (nonhydrolyzable GDP analogue) or anti-Gq/11 antibody. UTP failed to activate the $\mathrm{Cl}^{-}$current when the cells were dialyzed with nonhydrolyzable ATP analogues (ATPS or AMP-PNP) without ATP, suggesting that ATP hydrolysis is a prerequisite for the current activation. I CI.UTP was persistently activated with a mixture of ATP $\gamma S+$ ATP in the pipette, suggesting the involvement of phosphorylation reaction in the current activation process. Our results strongly suggest that $I_{\text {Cl.UTP }}$ is due to the activation of CFTR $\mathrm{Cl}^{-}$channels through $\mathrm{Gq} /$ 11-coupled $\mathrm{P} 2 \mathrm{Y}_{2}$ receptor-PLC-PKC signaling and ATP hydrolysis in mouse heart.

Key words: $\mathrm{Cl}^{-}$current, ventricular cell, $\mathrm{P} 2 \mathrm{Y}$ receptor, CFTR, ATP hydrolysis.

$\mathrm{E}_{\mathrm{x}}$ cellular space of the heart [1]. It is well known that the concentration of purines such as ATP is increased by hypoxia, ischemia, increased blood flow, and mechanical stretch [1-3]. The released purines, as paracrine or autocrine mediators, may regulate cardiac contraction, intracellular free- $\mathrm{Ca}^{2+}$ concentration, and cardiac ion channels [4] probably via cell-surface receptor families termed purine (or purinergic) receptors, which consist of a group of ligand-gated ion channels and $\mathrm{G}$ protein-coupled receptors, termed $\mathrm{P} 2 \mathrm{X}$ and $\mathrm{P} 2 \mathrm{Y}$ receptor families, respectively [2-7]. Pyrimidines such as uridine-5'-triphosphate (UTP) have been shown to be released from cardiac cells under certain pathophysiological conditions [8-10]. However, only a few studies have focused on the cardiac effect of UTP.

With respect to the regulation of cardiac chloride $\left(\mathrm{Cl}^{-}\right)$ channels by purines, it has been reported that extracellular ATP $\left(\mathrm{ATP}_{\mathrm{o}}\right)$ activates $\mathrm{Cl}^{-}$currents $\left(I_{\mathrm{Cl} \text {.ATP }}\right)$ in guinea pig atrial cells [11] and ventricular cells from rat [12] and mouse [13-15] hearts. Yamamoto-Mizuma et al. [15] showed that $I_{\text {Cl.ATP }}$ is regulated by pertussis toxin (a selective Gi-protein inhibitor)-independent and GDPS (a nonhydrolyzable GDP analogue)-sensitive intracellular signal pathways and is inhibited by suramin (a purinergic receptor antagonist). Further, the several properties [current-voltage $(I-V)$ relationships, anion permeability, effect of $\mathrm{Cl}^{-}$channel blockers, and single channel conductance] of $I_{\text {Cl.ATP }}$ were similar to those of cystic fibrosis transmembrane conductance regulator (CFTR) $\mathrm{Cl}^{-}$channels $[14,15]$. These results suggest that $\operatorname{ATP}_{\mathrm{o}}$ activates CFTR $\mathrm{Cl}^{-}$current via $\mathrm{P} 2 \mathrm{Y}$ receptors in mouse ventricular cells. In line with this, an RT-PCR study clearly confirmed an expression of the homologue of CFTR in mouse heart [14], and $\mathrm{ATP}_{\mathrm{o}}$ failed to activate any detectable $\mathrm{Cl}^{-}$currents in ventricular cells of $c f t r$ null mice [15]. It should be noted, however, that several protein kinase A (PKA) activators (isoprenaline, forskolin, and isobutyl methylxanthine), which are known to activate CFTR $\mathrm{Cl}^{-}$current in cardiac myocytes of many species, cannot activate any detectable $\mathrm{Cl}^{-}$current in mouse heart $[14,16]$. It is interesting that the stimulation of endogenous protein kinase $\mathrm{C}$ $(\mathrm{PKC})$ with phorbol 12,13-dibutyrate $(\mathrm{PDBu})$ activated

Received on Oct 3, 2006; accepted on Feb 8, 2007; released online on Feb 11, 2007; doi:10.2170/physiolsci.RP011406 Correspondence should be addressed to: Shintaro Yamamoto, Department of Physiology, Saga University Faculty of Medicine, 5-1-1 Nabeshima, Saga, 849-8501 Japan. Tel: +81-952-34-2277, Fax: +81-952-34-2013, E-mail: yamamot3@cc.saga-u.ac.jp 
CFTR-like $\mathrm{Cl}^{-}$current in mouse cardiac myocytes [14, 17].

The subtype of $\mathrm{P} 2 \mathrm{Y}$ receptor involved in the activation of $\mathrm{CFTR}^{-} \mathrm{Cl}^{-}$current is not clear. It has been reported that extracellular UTP $\left(\mathrm{UTP}_{\mathrm{o}}\right)$ modulates some cationic currents (ATP-sensitive potassium current [18], sodium current [19], and muscarinic potassium channels [20]) in heart, but the regulation of cardiac $\mathrm{Cl}^{-}$current by $\mathrm{UTP}_{\mathrm{o}}$ is still unknown.

In the heart, studies with the RT-PCR method have revealed expressions of $\mathrm{P} 2 \mathrm{Y}_{1,2,4,6}$ receptors in neonatal rat [21] and of $\mathrm{P} 2 \mathrm{Y}_{1,2,4,6,11,12,13,14}$ receptors in human [22]. For mouse cardiomyocytes, recent studies [23, 24] suggest that at least $\mathrm{P} 2 \mathrm{Y}_{1,2,46,11}$ receptors are functionally expressed in these cells. In pharmacological studies, the major agonists of the cloned human $\mathrm{P} 2 \mathrm{Y}$ receptors are ADP $\left(\mathrm{P}_{2} \mathrm{Y}_{1}\right), \mathrm{UTP} / \mathrm{ATP}\left(\mathrm{P} 2 \mathrm{Y}_{2}\right), \mathrm{UTP}\left(\mathrm{P} 2 \mathrm{Y}_{4}\right), \mathrm{UDP}$ $\left(\mathrm{P}_{6} \mathrm{Y}_{6}\right)$, ATP $\left(\mathrm{P} 2 \mathrm{Y}_{11}\right)$, 2-MeSADP $\left(\mathrm{P} 2 \mathrm{Y}_{12}\right)$, 2-MeSADP $\left(\mathrm{P} 2 \mathrm{Y}_{13}\right)$, and UDP-glucose $\left(\mathrm{P}_{2} \mathrm{Y}_{14}\right)[2,7]$. The rat $\mathrm{P} 2 \mathrm{Y}_{4}$ receptor is activated by both ATP and UTP [7]. As with the antagonism, subtype-selective $\mathrm{P} 2$ receptor antagonists are not known. However, it has been reported that suramin, a popular P2 receptor antagonist, effectively counteracts $\mathrm{P} 2 \mathrm{Y}_{1,2,11,12,13}$ receptors, but counteracts $\mathrm{P} 2 \mathrm{Y}_{4,6}$ receptors only weakly [7]. Pyridoxalphosphate-6-azophenyl-2',4'disulfonic acid (PPADS) is a popular nonselective $\mathrm{P} 2 \mathrm{X}$ receptor antagonist and inhibits $\mathrm{P} 2 \mathrm{Y}_{1}$ receptor potently, $\mathrm{P} 2 \mathrm{Y}_{4,6,13}$ receptors moderately, and $\mathrm{P} 2 \mathrm{Y}_{2,11,12}$ receptors only weakly [7]. Thus pharmacological studies with various receptor agonists and antagonists would serve to identify the subtype of $\mathrm{P} 2 \mathrm{Y}$ receptors.

On the other hand, the intracellular signaling reaction triggered by receptor stimulation may be different among the P2Y receptor subtypes. Based on the functional coupling to particular $G$ proteins and effecter proteins, the cloned P2Y receptors can broadly be categorized into a family of $\mathrm{Gq} / 11$-coupled receptors $\left(\mathrm{P} 2 \mathrm{Y}_{1,2,4,6,11}\right)$ that cause both an activation of protein kinase $C$ (PKC) and $\mathrm{Ca}^{2+}$ mobilization through the activation of phospholipase $\mathrm{C}$ (PLC), and a family of Gi-coupled receptors (P2 $\mathrm{Y}_{12,13 \text {, }}$ ${ }_{14}$ ) that inhibit adenylyl cyclase-protein kinase A (PKA) signaling $[2,4,6]$. It should be noted that $\mathrm{P} 2 \mathrm{Y}_{11}$ receptor can be coupled to Gs and adenylyl cyclase activation [23, 25].

In the present study, we examined extracellular UTPactivated $\mathrm{Cl}^{-}$current $\left(I_{\mathrm{Cl} \text {.UTP }}\right)$ in mouse ventricular cells to identify the subtype of $\mathrm{P} 2 \mathrm{Y}$ receptor and intracellular signaling pathway involved by using electrophysiological and pharmacological techniques. Our results strongly suggest that the cardiac $I_{\mathrm{Cl} \text {.UTP }}$ is due to an activation of CFTR $\mathrm{Cl}^{-}$channels via the $\mathrm{P} 2 \mathrm{Y}_{2}$ receptor-Gq/11-PLC-PKC signaling pathway and ATP hydrolysis. A preliminary account of this work has appeared in abstract form [26].

\section{MATERIAL AND METHODS}

Cell preparation. The Saga University Animal Care and Use Committee approved the use and treatment of all animals used in the experiments described here. The investigation confirms also with the Guiding Principles of the Physiological Society of Japan. Single ventricular myocytes from mouse hearts were isolated by using an enzymatic dispersion technique as previously described [15]. Briefly, mice (18-25 g, C-57BL/6J/black inbred, male) were anaesthetized with sodium pentobarbitone $(50 \mathrm{mg} /$ ml, I.P.). The chest was opened, and the heart was rapidly removed and perfused by using a modified Langendorff technique, with a physiological saline solution (PSS, see "Solutions and drugs") warmed to $37^{\circ} \mathrm{C}$ to wash out blood, then with a nominally $\mathrm{Ca}^{2+}$-free PSS until the heart ceased to beat, and finally with the $\mathrm{Ca}^{2+}$-free solution containing $0.1 \%$ collagenase (CLSII, Worthington, Lakewood, NJ, USA) and 1.0\% bovine serum albumin (BSA) for 20-30 min. The ventricles were removed and cell dissociation was achieved by gentle mechanical agitation of the tissue in high- $\mathrm{K}^{+}$, low- $\mathrm{Cl}^{-}$storage (modified $\mathrm{KB}$ ) solution (see "Solutions and drugs"), and the dissociated cells were stored in a refrigerator $\left(4^{\circ} \mathrm{C}\right.$ ) for later use (within 8 h). Only rod-shaped myocytes with clear cross-striations and no blebs were used in the experiments.

Electrophysiological techniques. The tight-seal wholecell patch-clamp technique was used to record whole-cell currents. Patch pipettes (1.5 mm O.D. borosilicate glass electrodes) had a tip resistance of 1-3 $\mathrm{M} \Omega$ when filled with pipette solution. Voltage-clamp recordings were performed using patch-clamp amplifiers (Model TM-1000; ACT ME, Tokyo, Japan), and membrane currents were filtered at a frequency of $2.5 \mathrm{kHz}$ and sampled at $5 \mathrm{kHz}$ with a Digidata 1322A and pCLAMP 9.0 software (Axon Instruments, Foster City, CA, USA). A 3 M KCl-agar bridge between the bath and the $\mathrm{Ag}-\mathrm{AgCl}$ reference electrode was used to minimize changes in liquid junction potential. Unless otherwise stated, current recordings were made by applying voltage pulses of $400 \mathrm{~ms}$ duration to various potentials (from -100 to $+100 \mathrm{mV}$ in $+20 \mathrm{mV}$ steps) from a holding potential of $0 \mathrm{mV}$ every $2 \mathrm{~s}$. When necessary, the current density was calculated by membrane capacitance, which was obtained using pCLAMP 9.0 software. Usually, 5 min was allowed for adequate cell dialysis after membrane rupture before the beginning of the voltage clamp protocol. All experiments were performed at room temperature, as previously described [15].

Solutions and drugs. The PSS for cell preparation contained (mM): $126 \mathrm{NaCl}, 10$ glucose, $4.4 \mathrm{KCl}, 5.0 \mathrm{MgCl}_{2}$, $1.5 \mathrm{CaCl}_{2}, 20$ taurine, 5.0 creatine, 5.0 sodium pyruvate, $1.0 \mathrm{NaHPO}_{4}, 10$ Hepes; pH 7.4 adjust with $\mathrm{NaOH} ; 300$ mOsm with mannitol. $\mathrm{Ca}^{2+}$-free PSS was prepared by simply omitting $\mathrm{CaCl}_{2}$ from the PSS. The modified $\mathrm{KB}$ solution for cell storage contained $(\mathrm{mM}): 70$ potassium 
glutamate, $20 \mathrm{KCl}, 1.0 \mathrm{MgCl}_{2}, 10 \mathrm{KH}_{2} \mathrm{PO}_{4}, 10$ taurine, 10 EGTA, 10 glucose, $0.1 \%$ albumin, $10 \beta$-hydroxybutric acid, and 10 Hepes; pH 7.2 with $\mathrm{KOH} ; 300$ mOsm with mannitol. For $I_{\mathrm{Cl}(\mathrm{P} 2 \mathrm{Y})}$ recording, the extracellular and intracellular solutions were chosen to maximize the recording of $\mathrm{Cl}^{-}$currents and to reduce possible contamination with cation currents and $\mathrm{Ca}^{2+}$-dependent currents. The standard extracellular solutions contained (mM): $77 \mathrm{NaCl}$, $0.8 \mathrm{MgCl}_{2}, 1.0 \mathrm{CaCl}_{2}, 5.0 \mathrm{CsCl}, 2.0 \mathrm{BaCl}_{2}, 0.2 \mathrm{CdCl}_{2}, 5.5$ glucose, 10 Hepes, 0.01 nicardipine; $\mathrm{pH} 7.4$ adjusted with $\mathrm{NaOH}$; total $\left[\mathrm{Cl}^{-}\right]_{\mathrm{o}}=90 \mathrm{mM} ; 310 \mathrm{mOsm}$ with mannitol. In some experiments, extracellular $\mathrm{NaCl}$ was replaced by an equimolar concentration $(77 \mathrm{mM})$ of sodium iodide or sodium aspartate. The standard intracellular pipette solution contained (mM) 140 NMDG, $90 \mathrm{HCl}, 5 \mathrm{MgATP}, 0.1$ TrisGTP, 20 EGTA, 10 Hepes; pH 7.3 adjusted with NMDG; total $\left[\mathrm{Cl}^{-}\right]_{\mathrm{i}}=90 \mathrm{mM} ; 290 \mathrm{mOsm}$ using mannitol. In some other experiments, MgATP was replaced with an equimolar amount $(5 \mathrm{mM})$ of adenosine 5 '-( $\beta, \gamma$-imido)triphosphate tetralithium salt hydrate (AMP-PNP: Sigma, St. Louis, MO, USA) or adenosine 5 '-[ $\gamma$-thio]triphosphate tetralithium salt (ATPS: Sigma). In others, $0.1 \mathrm{mM}$ Tris-GTP was replaced with $0.1 \mathrm{mM}$ guanosine 5 '-[ $\gamma$-thio]triphosphate (GTP $\gamma \mathrm{S}$; Sigma) or $1.0 \mathrm{mM}$ guanosine 5-[ $[\beta-$ thio]diphosphate (GDP $\beta S$; Sigma). Pipette solutions containing $10 \mathrm{mM} \mathrm{MgATP}$, or $5 \mathrm{MgATP}+5 \mathrm{mM}$ AMP-PNP, or $5 \mathrm{mM} \mathrm{MgATP}+5 \mathrm{mM} \mathrm{ATP} \gamma \mathrm{S}$ were also prepared. The osmolarity of all solutions was measured by using freezing point depression osmometers (Model OM-801; Vogel, Giessen, Germany).

The chemicals used were glibenclamide (Sigma), 5-nitro-2-(3-phenylpropylamino)-benzoate (NPPB; Sigma), diphenylamine-2-carboxylate (DPC; Sigma), 5-([4-Carboxyphenyl]methylene)-2-thioxo-3-([3-trifluoromethyl]phenyl)-4-thiazolidinone ( $\mathrm{CFTR}_{\mathrm{inh}}$-172; Sigma), 4,4'diisothiocyanostilben-2,2'-disulphonate (DIDS; Sigma), suramin (Sigma), pyridoxalphosphate-6-azophenyl-2',4'disulfonic acid (PPADS; Sigma), phorbol 12,13-dibutyrate (PDBu; Sigma), 4 $\alpha$-phorbol 12,13-didecanoate

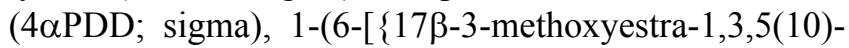
trien-17-yl $\}$ amino] hexyl)-1 $H$-pyrrole-2,5-dione (U73122; Sigma), 1-(6-[\{17ß-3-methoxyestra-1,3,5(10)trien-17-yl\}amino] hexyl)-2,5-pyrrolidine-dione (U73343; Calbiochem), bisindolylmaleimide-I (BIM-I; Sig$\mathrm{ma}$ ), and bisindolylmaleimide-V (BIM-V; Sigma). Extracellular nucleotides used were adenosine 5'-triphosphate disodium salt, (ATP; Sigma), uridine 5'-triphosphate disodium salt (UTP; Sigma), adenosine 5'-diphosphate sodium salt (ADP; Sigma), uridine 5'-diphosphate sodium salt (UDP; Sigma), and guanosine 5-triphosphate tris salt (GTP; sigma). Intracellular dialysis with anti-Gq/11 antibody has been described previously [27]. In brief, affinitypurified polyclonal antibody directed against 19 amino acids within the extreme carboxyl termini of Gq/11 (sc392) was purchased from Santa Cruz Biotechnology (San- ta Cruz, CA, USA). The cells were dialyzed for $\sim 10 \mathrm{~min}$ with a pipette solution containing a 1:100 dilution $(2 \mu \mathrm{g}$ $\left.\mathrm{ml}^{-1}\right)$ of anti-Gq/11 antibody. Heat-inactivated anti-Gq/11 antibody $\left(100^{\circ} \mathrm{C}\right.$ for $\left.20 \mathrm{~min}\right)$ was prepared as control. The osmolarity of the pipette solution was not altered by the inclusion of the antibody.

Data analysis. Permeability ratios (Fig. 2C) were calculated from the shifts in $E_{\text {rev }}$ according to the modified Goldman-Hodgkin-Katz equation: $P_{\mathrm{x}} P_{\mathrm{Cl}}^{-1}=\left(\left[\mathrm{Cl}^{-}\right]_{\mathrm{c}}\right.$ $\left.\exp \left[-\Delta E_{\text {rev }} \mathrm{F}\{\mathrm{RT}\}^{-1}\right]-\left[\mathrm{Cl}^{-}\right]_{\mathrm{S}}\right)\left[\mathrm{X}^{-}\right]_{\mathrm{S}}^{-1}$, where $\Delta E_{\mathrm{rev}}$ is the shift of reversal potential, $\left[\mathrm{Cl}^{-}\right]_{\mathrm{C}}$ and $\left[\mathrm{Cl}^{-}\right]_{\mathrm{S}}$ are the extracellular $\mathrm{Cl}^{-}$concentrations in the control (standard) and anion-substituted solutions, respectively, and $\left[\mathrm{X}^{-}\right]_{\mathrm{S}}$ is the concentration of the substituting anion $\mathrm{X}^{-}$. F/RT is the usual thermodynamic parameter. Concentration-response curves (Fig. 3A) to extracellular ATP or UTP were analyzed by using a Hill equation: response $=1 /(1+[\mathrm{EC} 50 /$ $\left.\{\mathrm{A}\}]^{n H}\right)$, where $[\mathrm{A}]$ is the agonist concentration, EC50 is the agonist concentration to achieve $50 \%$ of the maximum response, and $n H$ is the Hill coefficient. The currents were normalized to the maximum difference current in each tested cell. The data are expressed as mean $\pm \mathrm{SEM} ; n$ indicates the number of cells. Statistical comparisons were performed either by one-way ANOVA with a post-hoc test (Scheffe's multiple comparison test) for group data, or by Student's $t$ test when only two groups were compared. A two-tailed probability of $<0.05$ is taken to indicate statistical significance.

\section{RESULTS}

Figure 1A shows the time course of extracellular ATP $\left(\mathrm{ATP}_{\mathrm{o}}\right)$ or UTP $\left(\mathrm{UTP}_{\mathrm{o}}\right)$-induced whole-cell currents observed at $+80 \mathrm{mV}$ (solid circles) and $-80 \mathrm{mV}$ (open circles) in a mouse ventricular cell. The outward current at $+80 \mathrm{mV}$ began to increase after the application of $100 \mu \mathrm{M}$ $\mathrm{ATP}_{\mathrm{o}}$ and reached an almost steady level within $\sim 3 \mathrm{~min}$. The inward current at $-80 \mathrm{mV}$ also increased after $\mathrm{ATP}_{0}$, but the increase appeared to occur with little delay. In this experiment, $\operatorname{ATP}_{0}$ was replaced with $\mathrm{UTP}_{\mathrm{o}}(100 \mathrm{M})$ when the $\mathrm{ATP}_{\mathrm{o}}$-induced currents reached a steady level. This agonist replacement had little effect on the outward current at $+80 \mathrm{mV}$, whereas it resulted in a decrease of the inward current at $-80 \mathrm{mV}$. The average magnitude of outward and inward currents observed after UTP $_{\mathrm{o}}$ in 6 cells was $99.8 \pm 2.7 \%$ and $60.3 \pm 9.4 \%$ of the magnitude of $\mathrm{ATP}_{\mathrm{o}}$-induced outward and inward currents, respectively. Similar results were obtained when the order of agonist application was reversed (data not shown).

Figure 1B shows the whole cell currents elicited by various voltage pulses obtained during the course of the experiment shown in Fig. 1A. The mean $I-V$ relationship of the different currents between the current observed after UTP and that in control and the mean $I-V$ relationship of the current component, which was sensitive to the ago- 
A

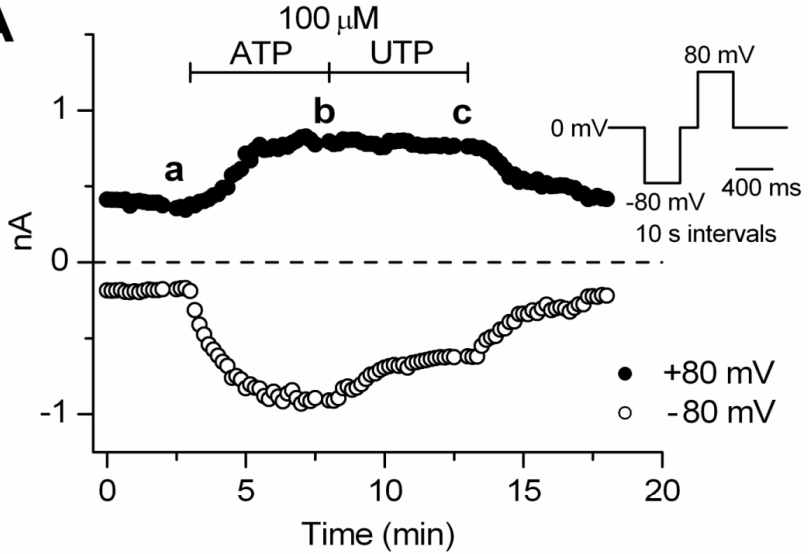

B

$\begin{array}{llll}\text { (a) Control (b) ATP } & \text { (c) UTP }\end{array}$

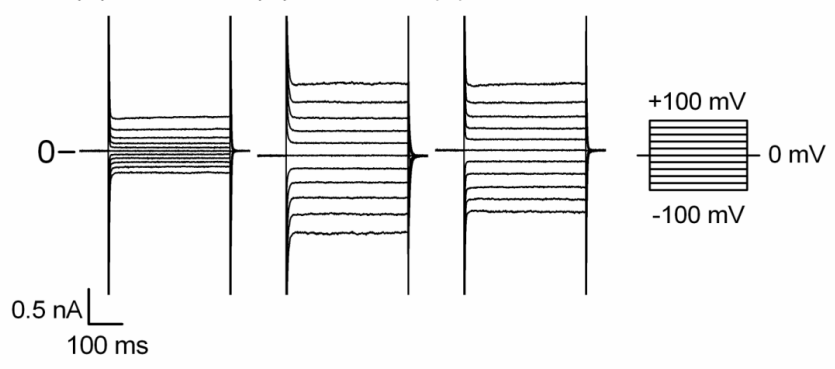

C

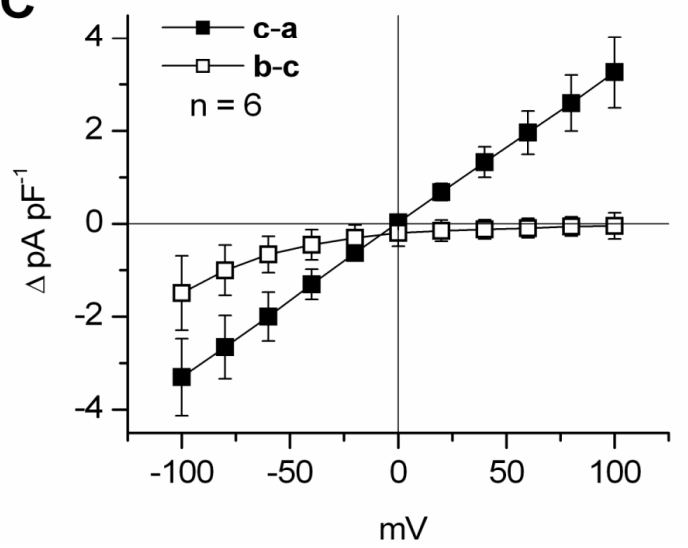

Fig. 1. Extracellular ATP- or UTP-induced membrane currents in mouse ventricular myocytes. A, the time course of extracellular ATP- or UTP-induced whole-cell currents at +80 $\mathrm{mV}$ (solid circles) and $-80 \mathrm{mV}$ (open circles) in a mouse ventricular cell exposed to ATP and UTP in standard extracellular solution. Either $100 \mu \mathrm{M}$ ATP or $100 \mu \mathrm{M}$ UTP was applied to the cell during the period indicated by a bar. Here and in subsequent similar figures, the pulse protocol is the same as shown in the inset of A. B, whole-cell currents induced by applying $400 \mathrm{~ms}$ voltage-clamp steps to membrane potentials from $100 \mathrm{mV}$ to $+100 \mathrm{mV}$ in $+20 \mathrm{mV}$ steps from a holding potential of $0 \mathrm{mV}$ every $2 \mathrm{~s}$. Currents were recorded at the points of a (control), b (ATP), and c (UTP) indicated in A. In subsequent similar figures, the step-pulse protocol is the same as that shown in the inset of $B$. C shows the mean $I-V$ relationship (c-a) of the difference current between the current observed after UTP and that in control $(n=6)$. The mean $I-V$ relationship (b-c) of the current fraction representing the current decrease observed on the agonist replacement from ATP to UTP is also shown $(n=6)$.
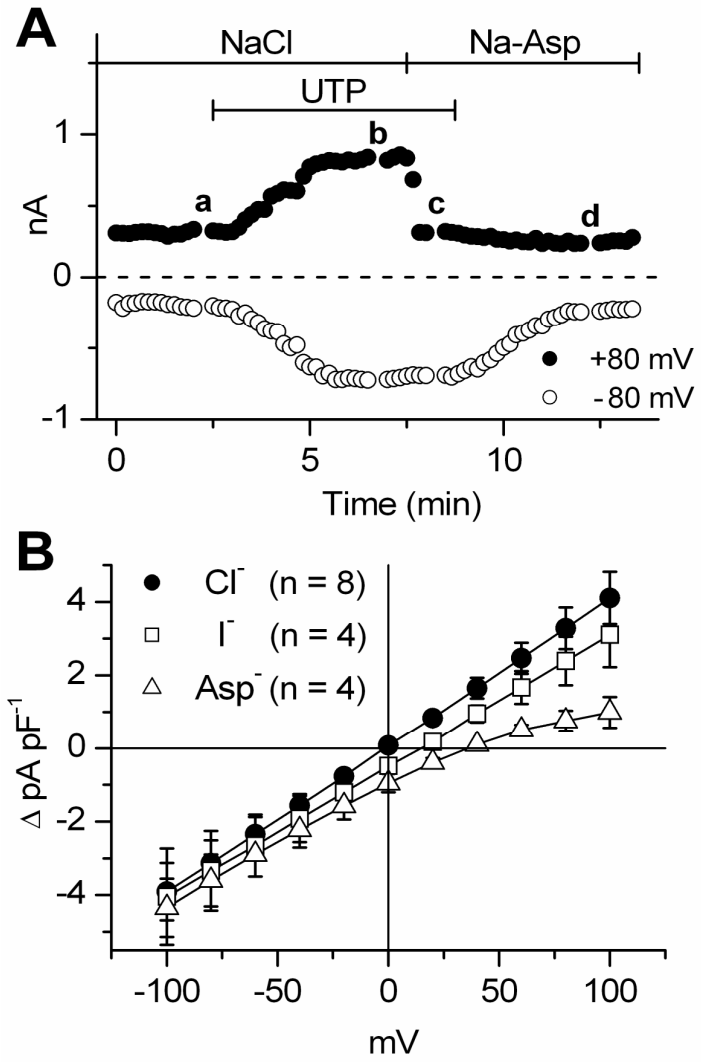

Fig. 2. Anion selectivity of extracellular UTP-induced currents in mouse ventricular myocytes. A, the time course of changes in whole-cell currents during the application of $100 \mu \mathrm{M}$ UTP (bar), as affected by switching the bathing solution from $\mathrm{NaCl}$ rich $(\mathrm{NaCl})$ to $\mathrm{Na}$-aspartate-rich ( $\mathrm{Na}-\mathrm{Asp})$ solution. The solution was changed as indicated by a bar. The Na-aspartaterich solution was prepared by replacing $77 \mathrm{mM}$ of $90 \mathrm{mM} \mathrm{NaCl}$ in standard ( $\mathrm{NaCl}$-rich) solution with an equimolar amount of $\mathrm{Na}$-aspartate. $\mathbf{B}$, the mean $I-V$ relationships of UTP-induced currents (difference currents, e.g., b-a and c-a in A) obtained in $\mathrm{NaCl}-, \mathrm{Nal}-$, and $\mathrm{Na}$-aspartate-rich solutions in 8,4 , and 4 cells, respectively. $\mathrm{Nal}$-rich and $\mathrm{Na}$-aspartate-rich solutions were prepared in a way similar to the above (A).

nist replacement from ATP to UTP, are shown in Fig. 1C. The latter $(\mathrm{b}-\mathrm{c})$ exhibited inward rectification with a reversal potential $\left(E_{\text {rev }}\right)$ of positive voltage, $E_{\text {rev }}$ being more positive than $+100 \mathrm{mV}$ in all tested cells $(n=6)$. In contrast, the $I-V$ relationship of the "UTP ${ }_{0}$-induced current" (c-a), like that of the $\mathrm{ATP}_{\mathrm{o}}$-induced $\mathrm{Cl}^{-}$current $\left(I_{\mathrm{Cl} \text {.ATP }}\right)$ [15], was almost linear. The mean $E_{\text {rev }}$ of the UTP ${ }_{0}$-induced current was $-1.7 \pm 4.4 \mathrm{mV}$, of which value being close to the predicted $\mathrm{Cl}^{-}$equilibrium potential $\left(E_{\mathrm{Cl}}=0\right.$ $\mathrm{mV}$ under symmetrical $\mathrm{Cl}^{-}$conditions). These findings confirm the previous results [15], which showed that ATP $_{\text {o }}$ activated both a nonselective cation current and a $\mathrm{Cl}^{-}$current, and they further suggest that $\mathrm{UTP}_{\mathrm{o}}$ activates the latter almost exclusively in mouse cardiac cells. We attempted to further characterize the $\mathrm{UTP}_{\mathrm{o}}$-induced current in the following way. 
We confirmed the $\mathrm{Cl}^{-}$-selectivity of the $\mathrm{UTP}_{\mathrm{o}}$-induced current. Figure 2A shows the effect of aspartate-rich solution with reduced $\left[\mathrm{Cl}^{-}\right]_{\mathrm{o}}$ on the UTP-induced current. When the bath solution was changed from high- $\left[\mathrm{Cl}^{-}\right]_{0}(90$ $\mathrm{mM})$ to low- $\left[\mathrm{Cl}^{-}\right]_{\mathrm{o}}\left(13 \mathrm{mM} \mathrm{Cl}^{-}+77 \mathrm{mM}\right.$ aspartate $)$ solution, the outward component of the $\mathrm{UTP}_{\mathrm{o}}$-induced current decreased markedly (Fig. 2A). Mean $I-V$ relationships for the $\mathrm{UTP}_{\mathrm{o}}$-induced current at high and low $\left[\mathrm{Cl}^{-}\right]_{\mathrm{o}}$ obtained in several of the experiments are shown in Fig. 2B (solid circles and open triangles). There was a positive shift of $E_{\text {rev }}$ with a reduction of $\left[\mathrm{Cl}^{-}\right]_{\mathrm{o}}$, and $E_{\text {rev }}$ at low $\left[\mathrm{Cl}^{-}\right]_{\mathrm{o}}$ was $+45 \pm 5 \mathrm{mV}(n=4)$, the value being close to $E_{\mathrm{Cl}}(+49.6$ $\mathrm{mV}$ ) predicted for the low $\left[\mathrm{Cl}^{-}\right]_{0}$ condition. These findings support the view that $\mathrm{UTP}_{0}$, like $\operatorname{ATP}_{\mathrm{o}}[13,15]$, activates the $\mathrm{Cl}^{-}$current in mouse ventricular cells. The inward rectification of the $\mathrm{UTP}_{\mathrm{o}}$-induced current in aspartate-rich bath solution (Fig. 2B, open triangles) can be explained by assuming that extracellular aspartate ions little or only slightly flow inwardly, but that intracellular $\mathrm{Cl}^{-}$ions substantially flow outwardly, generating a sizable inward current in this solution.

We examined also the $\mathrm{UTP}_{\mathrm{o}}$-induced $\mathrm{Cl}^{-}$current $\left(I_{\text {Cl.UTP }}\right)$ in $\mathrm{I}^{-}$-rich, $\mathrm{Cl}^{-}$-deficient bath solution $\left(77 \mathrm{mM} \mathrm{I}^{-}+\right.$ $13 \mathrm{mM} \mathrm{Cl}-)$. Its current-voltage $(I-V)$ relationship is shown in Fig. $2 \mathrm{~B}$ (open squares). $E_{\text {rev }}$ was $+20 \pm 6 \mathrm{mV}$ in this case. The $E_{\text {rev }}$ values obtained in $\mathrm{Cl}^{-}-$, aspartate-, and $\mathrm{I}^{-}$-rich solutions were used to calculate the permeability ratio of these anions (permeability ratio of ion $\mathrm{X}^{-}$with respect to $\left.\mathrm{Cl}^{-}, P_{\mathrm{x}} P_{\mathrm{Cl}}^{1}\right)$ according to a modified GoldmanHodgkin-Katz equation. In this calculation, $P_{\mathrm{I}} P_{\mathrm{Cl}}{ }^{-1}$ and $P_{\text {Asp }} P_{\mathrm{Cl}}{ }^{-1}$ were 0.47 and 0.14 , respectively. The anion selectivity of the current, $\mathrm{Cl}^{-}>$iodide $>$aspartate, is similar to that of PKA-activated CFTR Cl- current [28] in cardiac myocytes of many species and that of $I_{\mathrm{Cl} \text {.ATP }}[15]$ in mouse ventricular cells. This finding, together with the observation that both $I_{\mathrm{Cl} \text {.ATP }}$ and $I_{\mathrm{Cl} \text {.UTP }}$ exhibit similar current characteristics (Fig. 1), suggest that both $\mathrm{ATP}_{\mathrm{o}}$ and $\mathrm{UTP}_{\mathrm{o}}$ quite likely activate the same $\mathrm{Cl}^{-}$current. Since $\mathrm{ATP}_{\mathrm{o}}$ is thought to activate CFTR $\mathrm{Cl}^{-}$current through a stimulation of P2Y receptors in mouse ventricular cells $[14,15]$, $\mathrm{UTP}_{\mathrm{o}}$ was considered to activate CFTR $\mathrm{Cl}^{-}$current in these cells.

The above view was further supported by the following experiments in which the effects of various $\mathrm{Cl}^{-}$channel inhibitors on $I_{\mathrm{Cl}, \mathrm{UTP}}$ were examined. To see the direct effect of the inhibitors on the $\mathrm{Cl}^{-}$channel in these experiments, it was important to exclude the possible interaction of the inhibitors on the receptors. Especially, it is noteworthy that DIDS and other stilbene derivatives, which are popular $\mathrm{Cl}^{-}$transport inhibitors, do not affect $\mathrm{CFTR} \mathrm{Cl}^{-}$ channels [29], but potently antagonize $\mathrm{P} 2$ purinergic receptors $[1,28,30]$. Therefore we attempted to obtain a receptor-independent $\mathrm{Cl}^{-}$current, using GTP $\gamma \mathrm{S}$ (a nonhydrolyzable GTP analogue)-loaded cells. Since GTP hydrolysis is essential to terminate the signal transduction
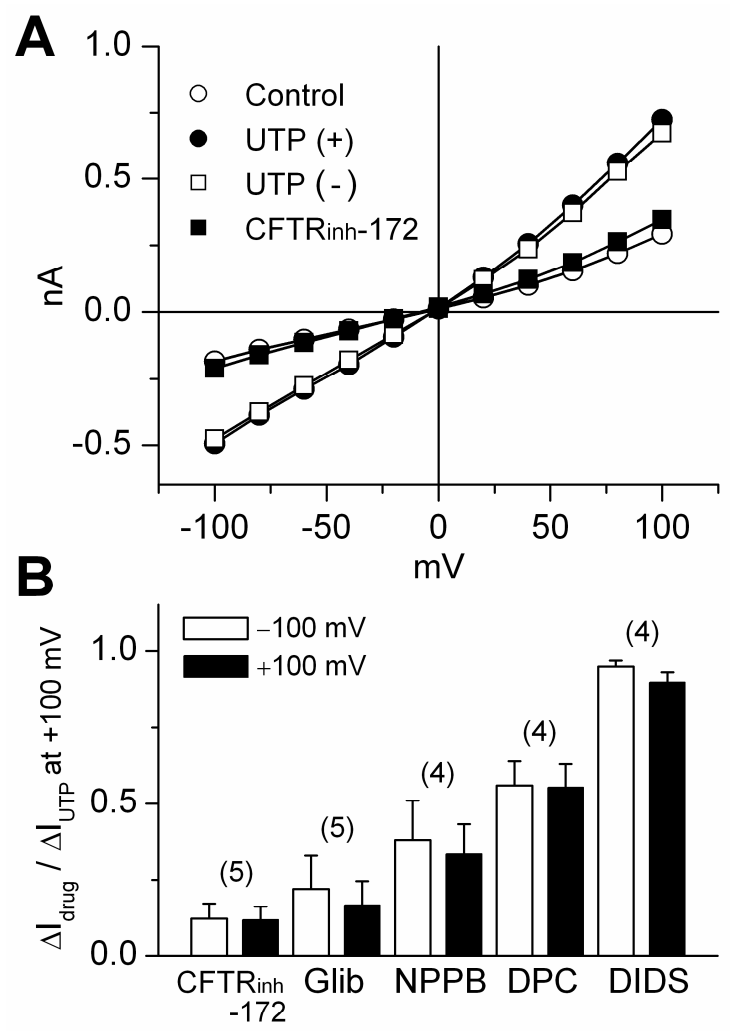

Fig. 3. Effects of $\mathrm{Cl}^{-}$channel inhibitors on $I_{\mathrm{Cl}, U T P}$. The pipette solution contained $0.1 \mathrm{mM}$ GTP $\gamma S$ to give a $\mathrm{Cl}^{-}$current persisting after the removal of UTP. A, a representative $I-V$ relationship of the whole-cell current obtained in control (open circles), after an application of UTP [solid circles; UTP (+)], 10 min after a washout of the UTP [open squares; UTP (-)] and after a further application of $10 \mu \mathrm{M} \mathrm{CFTR}$ inh $^{-172}$ (solid squares). $\mathbf{B}$, a summary of the inhibitory effect of $\mathrm{Cl}^{-}$channel blockers on persistently activated $\Delta I_{\text {CI,UTP }}$ in GTP $\gamma$ S-loaded cells. We examined $50 \mu \mathrm{M}$ glibenclamide (Glib, $n=5), 500 \mu \mathrm{M}$ DPC $(n=4), 100 \mu \mathrm{M}$ NPPB $(n=4), 10 \mu \mathrm{M} \mathrm{CFTR}_{\text {inh }}-172(n=$ $5)$, and $100 \mu \mathrm{M}$ DIDS $(n=4) . \Delta I_{\text {drug }} / \Delta I_{\text {UTP }}$ which represents the ratio of inhibitor-sensitive current components $\left(\Delta l_{\text {drug }}\right)$ to control $\Delta I_{\text {UTP }}$, was determined at +100 and $-100 \mathrm{mV}$. The data are expressed as mean \pm SEM.

processes linking receptor occupation and activation of effector protein, once the effector protein is activated by an agonist, the activation persists after the removal of the agonist in GTP $\gamma \mathrm{S}$-loaded cells. Indeed, it has been shown that in such cells $I_{\mathrm{Cl} \text {.ATP }}$ once activated by $\mathrm{ATP}_{\mathrm{o}}$, persists even after the removal of $\operatorname{ATP}_{\mathrm{o}}$ [15]. In the present study, similar persistent $I_{\mathrm{Cl}, \mathrm{UTP}}$ could be observed, and we examined the effects of $\mathrm{Cl}^{-}$channel inhibitors on the $I_{\mathrm{Cl} \text {,UTP }}$ in the absence of UTP.

Figure 3A shows the effect of $\mathrm{CFTR}_{\text {inh }^{-172}}$ (a thiazolidinone-derived selective CFTR $\mathrm{Cl}^{-}$channel inhibitor [31]) on the persistent $I_{\mathrm{Cl}, \mathrm{UTP}} I_{\mathrm{Cl}, \mathrm{UTP}}$ was almost completely inhibited by $10 \mu \mathrm{M}$ CFTR inh $^{-172}$ in a voltage-independent manner. The inhibitory effect developed quickly (within $\sim 3 \mathrm{~min}$ ) and was reversible $(n=4)$. Figure $3 \mathrm{~B}$ summarizes the effects of several inhibitors on $I_{\mathrm{C}, \mathrm{UTP}}$. Fifty micromo- 


\section{S. YAMAMOTO et al.}
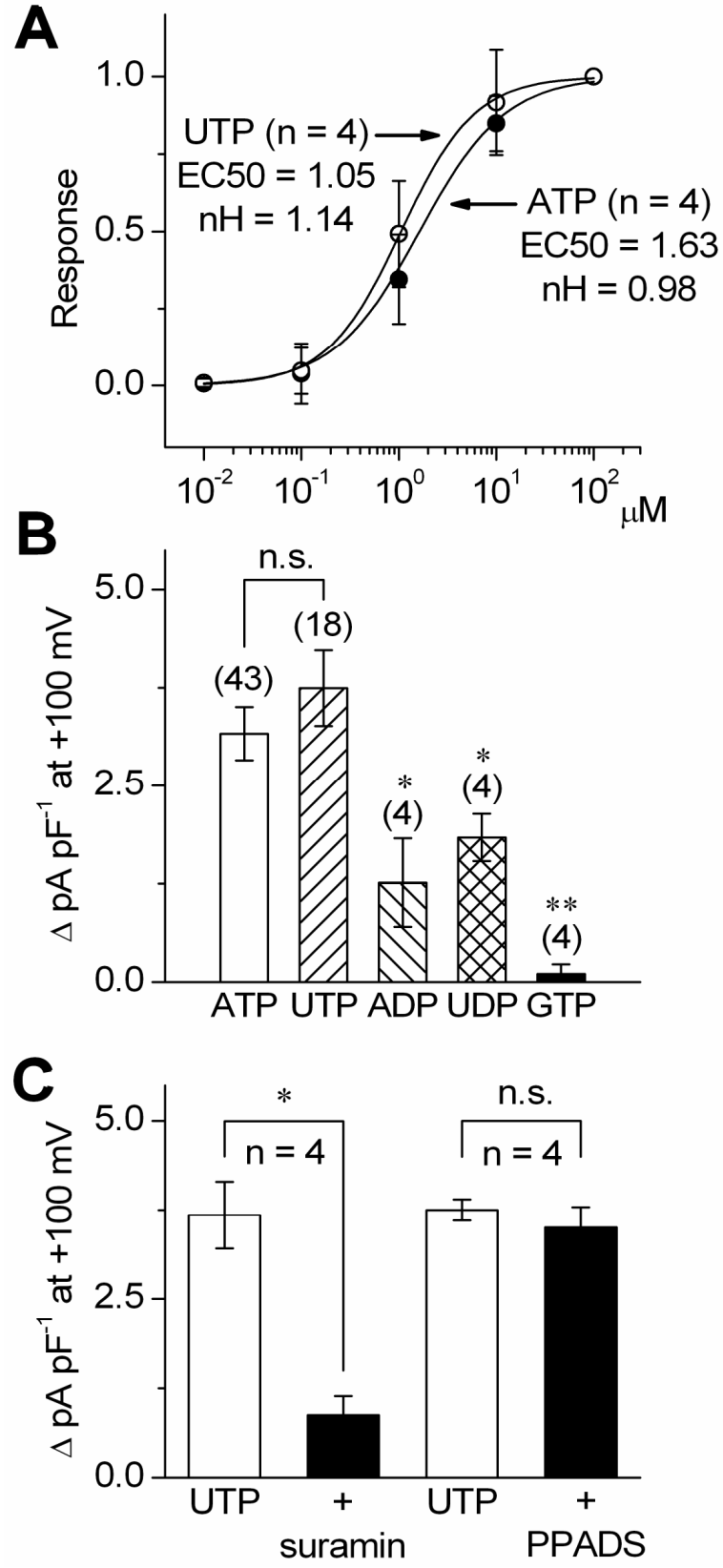

Fig. 4. Dependence of cardiac $\mathrm{Cl}^{-}$current on agonists and antagonists of purinergic receptors. $\mathbf{A}$, the dose-response relationships of extracellular ATP- or UTP-induced (difference) currents. Each point represents the mean of the data obtained in 4 different cells. For each curve, responses were normalized to the maximum response obtained at a maximal agonist concentration (100 $\mu \mathrm{M})$. The EC50 (concentration for half-maximal activation) and $n H$ (Hill coefficient) values were obtained by fitting the curve to the Hill equation. $\mathbf{B}$, the mean current density of the $\mathrm{Cl}^{-}$current at $+100 \mathrm{mV}$ obtained with a maximal concentration $(100 \mu \mathrm{M})$ of various agonists (ATP, $n=$ 43; UTP, $n=18$; ADP, $n=4$; UDP, $n=4$; GTP, $n=4$ ). The symbols $*$ and $* *$, significantly smaller than the value for ATP with $P<0.05$ and 0.01 , respectively. C, the mean current density of UTP-induced (difference) current obtained at $+100 \mathrm{mV}$ in the presence and absence of $100 \mu \mathrm{M}$ suramin $(n=4)$ or 100 $\mu \mathrm{M}$ PPADS $(n=4)$. The symbol $*$, significant $(P<0.05)$ reduction of the current after suramin. n.s., not significantly different. lar glibenclamide, $500 \mu \mathrm{M}$ DPC, and $100 \mu \mathrm{M}$ NPPB inhibited $I_{\mathrm{Cl} \text { UTP }}$ in a voltage-independent manner, whereas $I_{\mathrm{Cl}, \mathrm{UTP}}$ was only slightly sensitive to $100 \mu \mathrm{M}$ DIDS. These results support the view that $\mathrm{UTP}_{\mathrm{o}}$ activates $\mathrm{CFTR} \mathrm{Cl}^{-}$ current in mouse ventricular cells.

We compared the potency of $\mathrm{ATP}_{\mathrm{o}}$ and $\mathrm{UTP}_{\mathrm{o}}$ for an activation of the $\mathrm{Cl}^{-}$current. Figure 4A shows the dose-response relationship for each agonist to activate the $\mathrm{Cl}^{-}$ current, where the magnitude of the $\mathrm{Cl}^{-}$current activated at $+100 \mathrm{mV}$ in standard bath solution was evaluated at various agonist concentrations. By fitting the curve to a Hill equation, the values of EC50 (concentration for halfmaximal activation) and $\mathrm{nH}$ (Hill coefficient) were calculated. EC50 and $\mathrm{nH}$ were $1.6 \mu \mathrm{M}$ and 0.98 for $\mathrm{ATP}_{\mathrm{o}}$, and $1.1 \mathrm{M}$ and 1.14 for $\mathrm{UTP}_{\mathrm{o}}$, indicating that $\mathrm{ATP}_{\mathrm{o}}$ and $\mathrm{UTP}_{\mathrm{o}}$ had an almost equal potency for activation of the $\mathrm{Cl}^{-}$current. The similar dose-response relationship of $\mathrm{ATP}_{\circ}$ and $\mathrm{UTP}_{\mathrm{o}}$ for the activation of $\mathrm{Cl}^{-}$current is in line with the view that these agonists stimulate the receptor of the same type to activate the same $\mathrm{Cl}^{-}$current. The agonist potency was examined also for other nucleotides (ADP, UDP, and GTP). In the graph shown in Fig. 4B, the magnitude of the $\mathrm{Cl}^{-}$current at $+100 \mathrm{mV}$ activated by $100 \mathrm{M}$ of various agonists is compared. The data suggest that the potency order for activation of the $\mathrm{Cl}^{-}$current is UTP $=$ATP $>$UDP $=\mathrm{ADP}$.

According to the previous studies on $\mathrm{P} 2 \mathrm{Y}$ receptor subtypes [7], the potency order of agonists for the activation of $\mathrm{Cl}^{-}$current (Fig. 4B) appears to coincide with the property of $\mathrm{P} 2 \mathrm{Y}_{2}$ and $\mathrm{P} 2 \mathrm{Y}_{4}$ receptors. To further identify the $\mathrm{P} 2 \mathrm{Y}$ receptor subtype involved, we examined the effects of $\mathrm{P} 2 \mathrm{Y}$ receptor-antagonist on the activation of $I_{\mathrm{Cl} \text {.UTP }}$ An earlier report [15] showed that the activation of cardiac $I_{\text {Cl.ATP }}$ was inhibited by suramin (a popular P2Y receptor antagonist). We attempted to see the effects of suramin as well as another P2Y antagonist, pyridoxalphosphate-6-azophenyl-2',4'-disulfonic acid (PPADS), on $I_{\mathrm{Cl} \text { UTP }}$ Figure $4 \mathrm{C}$ summarizes the results. Suramin $(100 \mu \mathrm{M})$ strongly inhibited $I_{\text {Cl.UTP }}$ whereas PPADS $(100 \mu \mathrm{M})$ exerted little effect on the $I_{\text {Cl.UTP }}$ The magnitude of $I_{\mathrm{Cl} . \text { UTP }}$ at $+100 \mathrm{mV}$ observed after antagonists was $27.1 \pm 8.8 \%(n=4)$ and $92.9 \pm 4.1 \%(n$ $=4$ ) of control for suramin and PPADS, respectively. It has been shown that PPADS can only weakly antagonize P2 $\mathrm{Y}_{2,11,12}$ receptors, though it substantially inhibits other $\mathrm{P} 2 \mathrm{Y}$ receptor subtypes [7]. Thus if the data for the agonist potency (Fig. 4B) and the ineffectiveness of PPADS on $I_{\text {Cl.UTP }}$ (Fig. $4 \mathrm{C}$ ) are taken into consideration together, our data appear to suggest the involvement of the $\mathrm{P}_{2} \mathrm{Y}_{2}$ receptor in the activation of $I_{\mathrm{Cl} \text {.UTP }}$ in mouse heart.

Most $\mathrm{P} 2 \mathrm{Y}$ receptor subtypes expressed in the heart may be coupled to $\mathrm{Gq} / 11$ protein and may regulate the production of PKC via an activation of phospholipase C (PLC) [1]. Although previous reports $[14,15]$ showed that an activation of $I_{\text {Cl.ATP }}$ involves PTX (a selective Gi protein inhibitor)-insensitive $\mathrm{G}$ protein and that $I_{\mathrm{Cl} \text {.ATP }}$ is regulated 
A Control
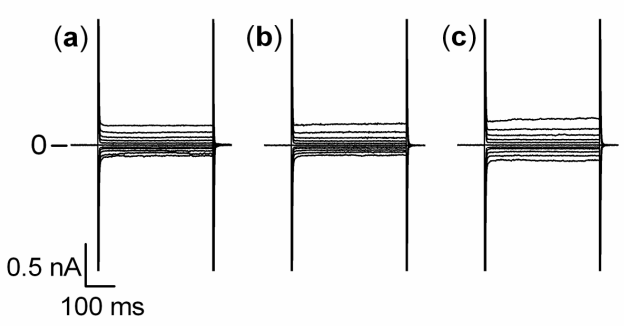

B

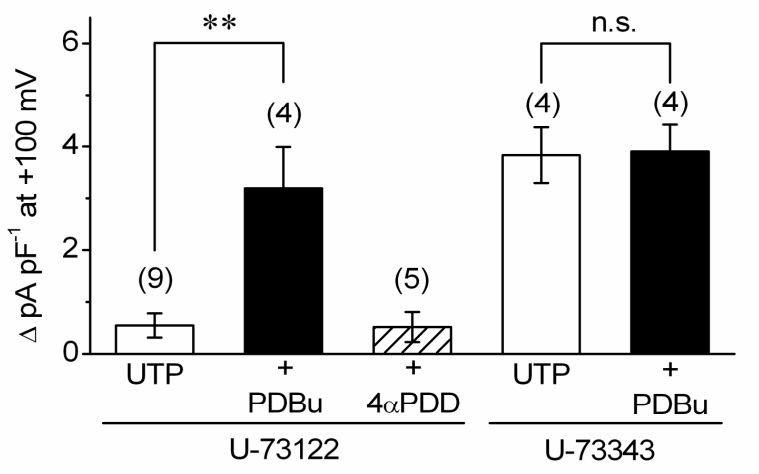

C

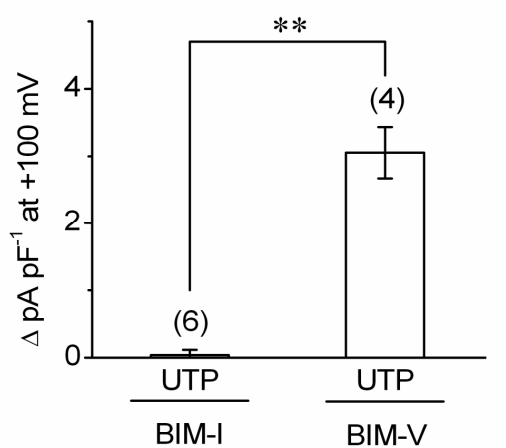

Fig. 5. Role of PLC and PKC in the activation of $I_{\text {CIUTP }} A$, the original current tracings showing the effects of UTP $(100 \mu \mathrm{M})$ and PDBu $(100 \mathrm{nM})$ on the whole-cell currents in the presence of U-73122 (5 $\mu \mathrm{M})$. Drugs were applied to the cell consecutively as indicated by a bar. B, a summary of the data showing the effect of UTP $(100 \mu \mathrm{M})$ and PDBu $(100 \mathrm{nM})$ on the membrane currents in the presence of U-73122 $(5 \mu \mathrm{M}$, left) or U-73343 (5 $\mu \mathrm{M}$, right). The effects of $4 \alpha \mathrm{PDD}(100 \mu \mathrm{M})$ with U-73122 is also shown. C, The density of UTP $(100 \mu \mathrm{M})$ induced currents obtained in the cells that were pretreated for 10 min with BIM-I (100 nM, left) or BIM-V (100 nM, right). In B and $C$, the data represent the density of the currents activated by agonists (difference currents) at $+100 \mathrm{mV}$. ** at $P<0.01$. n.s., not significantly different.

by $\mathrm{PKC}$, detailed signaling pathways linking purinergic stimulation to PKC activation are unknown. To clarify whether the process of Gq/11 protein-PLC-PKC signaling is responsible for an activation of $I_{\mathrm{Cl} \text {.UTP, }}$ we examined the effects of BIM-I (a specific PKC inhibitor), U-73122 (a specific PLC inhibitor), GDPS (nonhydrolyzable GDP analogue) and anti-Gq/11 antibody on the activation of $I_{\text {Cl.UTP }}$

When the cell was pretreated with $\mathrm{U}-73122,100 \mu \mathrm{M}$ $\mathrm{UTP}_{\mathrm{o}}$ activated $I_{\mathrm{Cl} \text {.UTP }}$ only a small amount or slightly
A Anti-Gq antibody (pipette)

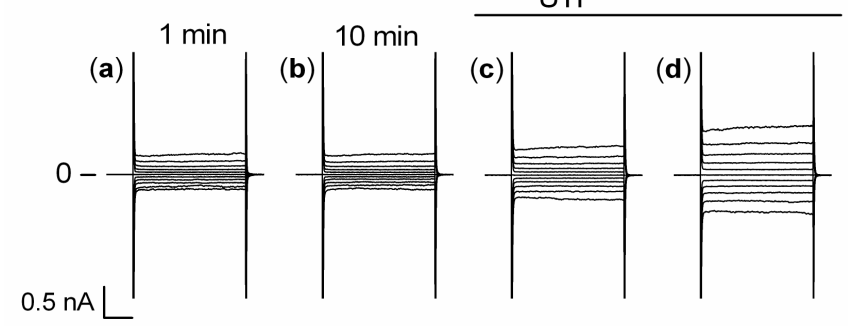

B

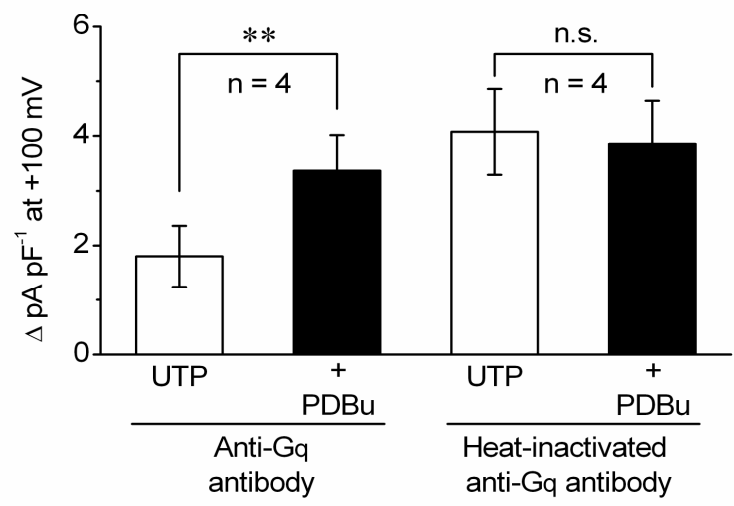

Fig. 6. Involvement of $\mathrm{Gq} / 11$ protein in the activation of $I_{\text {CI.UTP. }}$ A, the original current tracings showing the effects of UTP $(100 \mu \mathrm{M})$ and PDBu (100 nM) on the whole-cell currents in a cell dialyzed with pipette solution containing anti-Gq/11 antibody $\left(2 \mathrm{mg} \mathrm{ml}^{-1}\right)$. The drugs were applied to the cell consecutively as indicated by a bar. The records (a) and (b), which were obtained, respectively, 1 and $10 \mathrm{~min}$ after membrane rupture, show that the basal currents were not changed by intracellular dialysis of anti-Gq/11 antibody. B, the summary of the data showing the effects of UTP $(100 \mu \mathrm{M})$ and PDBu (100 $\mathrm{nM})$ on the membrane currents in cells dialyzed with anti-Gq/ 11 antibody (2 $\mathrm{mg} \mathrm{ml}^{-1}$, left) or heat-inactivated anti- $\mathrm{G}_{\alpha} \mathrm{q} / 11$ antibody ( $2 \mathrm{mg} \mathrm{ml}^{-1}$, right). The data represent the density of the currents activated by agonists (difference currents) at $+100 \mathrm{mV}$. The symbol **, significant $(P<0.01)$ increase in the current after PDBu. n.s., not significantly different.

(Fig. 5Ac). The application of $100 \mathrm{nM} \mathrm{PDBu}$, an agent that activates PKC without involving PLC, could induce $I_{\text {Cl.UTP }}$ of large amplitude in the presence of $5 \mu \mathrm{M} \mathrm{U}$ 73122, as expected (Fig. 5Ad). Figure 5B summarizes the results of the experiments in which the effects of $\mathrm{UTP}_{0}$, $\mathrm{PDBu}$, and $4 \alpha \mathrm{PDD}$ (inactive analogue of PDBu) on the whole cell current were examined in the presence of $U$ 73122 or U-73343 (inactive analogue of U-73122). In the presence of $5 \mu \mathrm{M} \mathrm{U}-73122(n=4), 100 \mu \mathrm{M} \mathrm{UTP}{ }_{\mathrm{o}}$ or UTP $_{\mathrm{o}}$ $+100 \mathrm{nM} 4 \mathrm{PDD}$ induced a current of $0.5 \pm 0.2$ or $0.4 \pm 0.3$ pA pF ${ }^{-1}$, respectively, whereas $\mathrm{UTP}_{\mathrm{o}}+100 \mathrm{nM}$ PDBu induced a current of $3.2 \pm 0.8 \mathrm{pA} \mathrm{pF}^{-1}$. In the presence of 5 M U-73343 $(n=4), \mathrm{UTP}_{\mathrm{o}}$ or $\mathrm{UTP}_{\mathrm{o}}+\mathrm{PDBu}$ induced a current whose amplitude $\left(3.8 \pm 0.5\right.$ or $4.0 \pm 0.5 \mathrm{pA} \mathrm{pF}^{-1}$, respectively) was comparable to that of $I_{\mathrm{Cl} \text {.UTP }}$ in the absence of the PLC inhibitor (Fig. 4). When the cell was 
pretreated with BIM-I (100 nM) for 10 min (Fig. 5C), 100 $\mu \mathrm{M} \mathrm{UTP}{ }_{\mathrm{o}}$ activated $I_{\mathrm{Cl} \text {.UTP }}$ only slightly $(n=6)$, whereas $100 \mu \mathrm{M} \mathrm{UTP}{ }_{\mathrm{o}}$ induced a current of $3.1 \pm 0.4 \mathrm{pA} \mathrm{pF}^{-1}$ in the presence of $100 \mathrm{nM}$ BIM-V (inactive analogue of BIM-I, $n=4)$.

In Fig. 6, we examined the effect of anti-Gq/11 antibody on the activation of $I_{\mathrm{Cl} \text {.UTP }}$ Our antibody was an affinity-purified polyclonal antibody directed against 19 amino acids within the extreme carboxyl termini of Gq/11, and the inhibitory effect of its intracellular application on the $\mathrm{Gq} / 11$-dependent system has been described previously [27]. As shown in Fig. 6A, the intracellular dialysis with anti-Gq/11 antibody itself appeared to have little effect on the whole cell current (b). The application of 100 $\mu \mathrm{M} \mathrm{UTP}{ }_{\mathrm{o}}$ activated $I_{\mathrm{Cl} \text { UTP }}$ only slightly in this condition (c). Again, $100 \mathrm{nM}$ PDBu could activate $I_{\text {Cl.UTP }}$ of large amplitude (d). Figure 6B summarizes the results of the experiments in which the effects of $\mathrm{UTP}_{\mathrm{o}}$ and PDBu on the whole cell current were examined in the presence of the intracellular antibody or heat-inactivated antibody. With the raw antibody $(n=4), 100 \mu \mathrm{M} \mathrm{UTP}_{\mathrm{o}}$ induced a current of $1.8 \pm 0.6 \mathrm{pA} \mathrm{pF}^{-1}$, whereas UTP $+100 \mathrm{nM} \mathrm{PDBu}$ induced a current of $3.7 \pm 0.7 \mathrm{pA} \mathrm{pF}^{-1}$. In the cells with the inactivated antibody $(n=4)$, $\mathrm{UTP}_{\mathrm{o}}$ or $\mathrm{UTP}_{\mathrm{o}}+\mathrm{PDBu}$ induced a current whose amplitude $(4.1 \pm 0.8$ or $4.2 \pm 1.0 \mathrm{pA}$ $\mathrm{pF}^{-1}$, respectively) was comparable to that of control $I_{\text {Cl.UTP }}$ (Fig. 4). We confirmed that the activation of $I_{\text {Cl.UTP }}$ was almost completely abolished in ventricular cells $(n=$ 5) dialyzed with $1 \mathrm{mM}$ GDPS (data not shown). These results suggest that $\mathrm{UTP}_{\mathrm{o}}$ activates the $\mathrm{Cl}^{-}$current via $\mathrm{Gq} /$ 11-coupled $\mathrm{P} 2 \mathrm{Y}_{2}$ receptors linked to the PLC-PKC signaling pathway in mouse ventricular cells.

PKC may mediate protein phosphorylation as a final step in the process of $I_{\text {Cl.UTP }}$ activation. It has been shown that the activation of CFTR $\mathrm{Cl}^{-}$channels requires both ATP hydrolysis and phosphorylation reactions [32]. We tested whether the activation of $I_{\mathrm{Cl} \text {.UTP }}$ also involves such processes by using hydrolysis-resistant ATP analogues (ATP $\gamma \mathrm{S}$ and AMP-PNP). We prepared pipette solutions of five types, i.e., those containing $5 \mathrm{mM}$ ATP $\gamma \mathrm{S}$ or $5 \mathrm{mM}$ AMP-PNP without ATP, and those containing $10 \mathrm{mM}$ ATP or $5 \mathrm{mM} \mathrm{ATP}+5 \mathrm{mM} \mathrm{ATP} \gamma \mathrm{S}$ or $5 \mathrm{mM}$ ATP $+5 \mathrm{mM}$ AMPPNP.

When the cells were dialyzed with pipette solutions containing only ATP $\gamma \mathrm{S}$ or AMP-PNP, an application of $\mathrm{UTP}_{\mathrm{o}}(100 \mu \mathrm{M})$ could induce little or no $\mathrm{Cl}^{-}$current in these cells (data not shown), suggesting that ATP hydrolysis is a necessary event for the activation of $I_{\mathrm{Cl} \text {.UTP }}$ When the pipette solution containing ATPS + ATP was used, the application of $\mathrm{UTP}_{\mathrm{o}}(100 \mu \mathrm{M})$ induced the $\mathrm{Cl}^{-}$current (Fig. 7A), as in the cells dialyzed with ATP alone. However, the deactivation of $I_{\text {Cl.UTP }}$ after the withdrawal of UTP was very slow in this case (Fig. 7A). The magnitude of $I_{\text {Cl.UTP }}$ at $+100 \mathrm{mV}$ was $6.6 \pm 0.7 \mathrm{pA} \mathrm{pF}^{-1}(n=4)$ in the presence of $\mathrm{UTP}_{\mathrm{o}}$, and it was $5.6 \pm 0.8 \mathrm{pA} \mathrm{pF}^{-1}$ at $15 \mathrm{~min}$
$\mathbf{A}_{5 \text { ATP }+5 \text { ATP } \gamma S}$
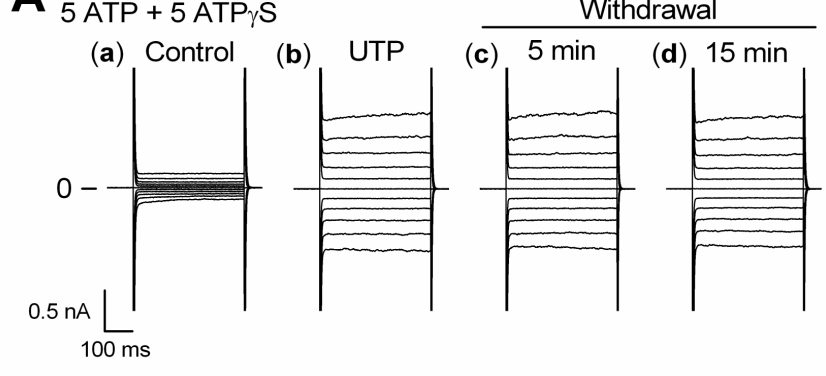

B

5 ATP + 5 AMP-PNP
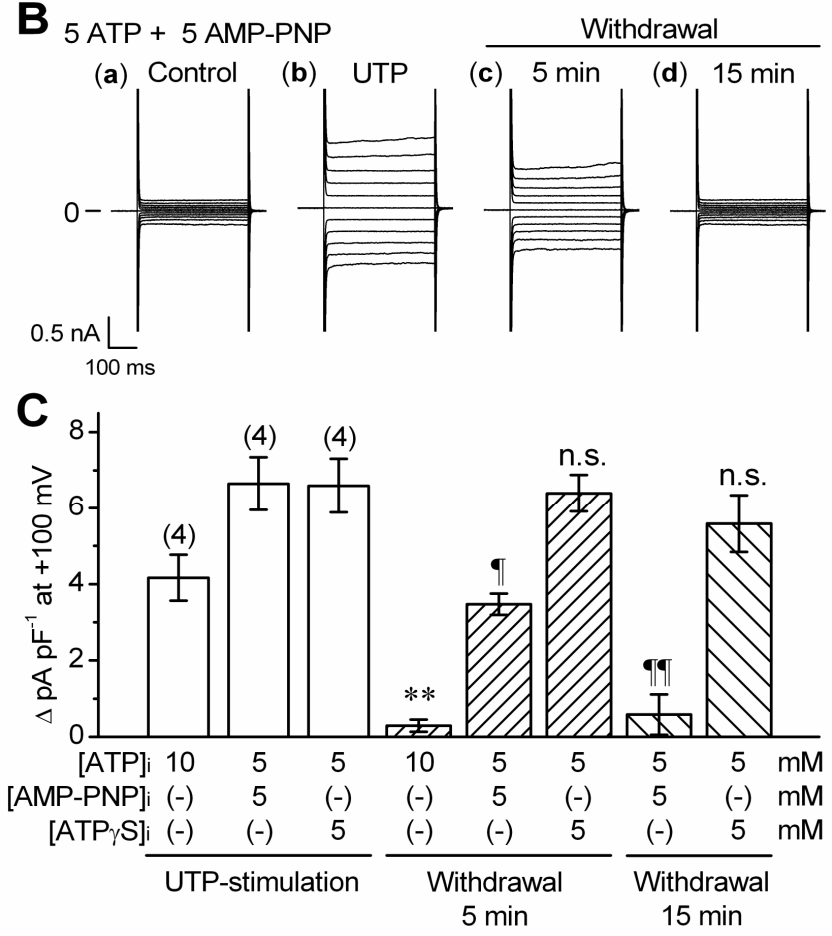

Fig. 7. The modulation of $I_{\text {CI.UTP }}$ activation by intracellular poorly hydrolyzable ATP analogues. A, original current tracings showing the effects of UTP $(100 \mu \mathrm{M})$ on the whole-cell currents in a cell dialyzed with pipette solution containing 5 mM ATP and 5 mM ATP $\gamma$ S. (a), control; (b), after application of $100 \mu \mathrm{M}$ UTP. Records obtained 5 and $15 \mathrm{~min}$ after the withdrawal of UTP are also shown (c and d). B, similar to A, but the cell was dialyzed with a pipette solution containing $5 \mathrm{mM}$ ATP and 5 mM AMP-PNP. C, a summary of the data showing the magnitude of UTP-induced currents (white columns) and the rate of current deactivation after agonist withdrawal (hatched columns) observed in cells dialyzed with a pipette solution containing $5 \mathrm{mM}$ ATP $+5 \mathrm{mM}$ ATP (ATP, $n=4$ ), $5 \mathrm{mM}$ ATP $+5 \mathrm{mM}$ ATP $\gamma \mathrm{S}$ (ATPS, $n=4$ ), or $5 \mathrm{mM} \mathrm{ATP}+5 \mathrm{mM}$ AMPPNP (AMP-PNP, $n=4$ ). The data represent the density of the currents activated by UTP (difference currents) at $+100 \mathrm{mV}$. The symbol $*$, significantly smaller than the control UTP-induced current (ATP) at $P<0.05$. The symbols $\uparrow$ and $\uparrow \uparrow$, significantly smaller than the control UTP-induced current (AMPPNP) at $P<0.05$ and 0.01 , respectively. n.s., not significantly different from the control UTP-induced current (+ATP $\gamma \mathrm{S})$.

after the agonist removal (Fig. 7C). This contrasted with the observation that $I_{\text {Cl.UTP }}$ activated in the cells dialyzed only with ATP disappeared almost completely within 5 
min after agonist removal (Figs. 1A, 2A, and 5C). The slow deactivation may be explained as follows. Since AT$\mathrm{P} \gamma \mathrm{S}$ can be a phosphate donor in phosphorylation reaction, and since thiophosphoprotein, a product of phosphorylation with -thiophosphate, is poorly hydrolyzable, phosphorylation, once induced with ATP $\gamma \mathrm{S}$ would persist after a withdrawal of stimulation, though phosphorylation induced with ATP would subside rapidly. Our findings suggest that a phosphorylation step is present in the activation of $I_{\text {Cl.UTP }}$

On the other hand, when the pipette solution contained AMP-PNP + ATP, the deactivation of $I_{\text {Cl.UTP }}$ was also slow, though its rate of deactivation was faster than that observed with ATP $\gamma \mathrm{S}$ (Fig. 7B). The magnitude of $I_{\mathrm{Cl} . \text { UTP }}$ still remaining 5 min after agonist removal was $3.5 \pm 0.3$ $\mathrm{pA} \mathrm{pF}^{-1}(n=4)$, of which the value was about $50 \%$ of that seen before agonist removal $\left(6.7 \pm 0.7 \mathrm{pA} \mathrm{pF}^{-1}\right.$; Fig. 6C). Since AMP-PNP may not act as a phosphate donor, the slow current deactivation after this agent cannot be explained by a slow dephosphorylation. We consider the phenomenon observed here to be similar to the persistent opening of CFTR channels produced specifically with AMP-PNP [33]. To explain this sustained channel opening, a specific behavior of nucleotide-binding domains (NBDs) included in the channel protein has been proposed (see DISCUSSION).

\section{DISCUSSION}

The major findings of the present investigation include (i) a demonstration that $\mathrm{UTP}_{\mathrm{o}}$ activates a $\mathrm{Cl}^{-}$current $\left(I_{\mathrm{Cl} \text { UTP }}\right)$ in mouse ventricular myocytes (Fig. 1A); (ii) an inhibition of $I_{\mathrm{Cl}, \mathrm{UTP}}$ by $\mathrm{CFTR}_{\mathrm{inh}}-172$, but no inhibition by DIDS (Fig. 3); (iii) a potency order of agonists for activation of the $\mathrm{Cl}^{-}$current to be UTP = ATP $>$UDP = ADP (Fig. 4B); (iv) an inhibition of the activation of $I_{\mathrm{Cl} \text {.UTP }}$ by suramin, but not by PPADS (Fig. 4C); (v) an inhibition of $I_{\text {Cl.UTP }}$ activation by PKC or PLC inhibitors (Fig. 5) and anti-Gq/ 11 antibody (Fig. 6); and (vi) a modulation of $I_{\mathrm{Cl} \text {.UTP }}$ activation by the intracellular nonhydrolyzable ATP analogues (Fig. 7). These results were believed to suggest that $I_{\mathrm{Cl} \text { UTP }}$ is due to an activation of $\mathrm{CFTR} \mathrm{Cl}^{-}$channels via $\mathrm{P}_{2} \mathrm{Y}_{2}$ receptor linked to the Gq/11-PLC-PKC signaling pathway and ATP hydrolysis in mouse ventricular myocytes.

The coupling of several P2Y receptor subtypes, including the $\mathrm{P}_{2} \mathrm{Y}_{2}$ receptor to PLC and PKC, is well established in many previous studies $[1-4,6,7]$, and the cloned $\mathrm{P} 2 \mathrm{Y}_{2}$ receptor has been reported to be UTP/ATP-sensitive and coupled to $\mathrm{Gq} / 11$ protein to activate PKC through PLC stimulation $[2,4,6]$. The present results obtained from native mouse ventricular cells are in agreement with these concepts. The expression of $\mathrm{P} 2 \mathrm{Y}_{2}$ receptor in mouse heart has been confirmed with a real-time PCR method [24].

The deactivation of $I_{\mathrm{Cl} \text {.UTP }}$ after agonist removal was slow when the cells were dialyzed with a solution containing a mixture of ATP and ATP $\gamma$ S (Fig. 7), and this finding was taken to support the view that the phosphorylationdephosphorylation cycle is related to the activation and deactivation of the current. It is of interest that the current deactivation after agonist removal was also slow in the cells dialyzed with a mixture of ATP and AMP-PNP (Fig. 7). Since AMP-PNP cannot cause phosphorylation reaction, a mechanism other than the phosphorylation-dephosphorylation cycle must be considered to explain this slow current deactivation. Hwang et al. [33] observed in guinea pig ventricular cells that phosphorylated $\mathrm{CFTR} \mathrm{Cl}^{-}$channels remained open for many minutes when AMP-PNP was present intracellularly. As an explanation of this phenomenon, it has been proposed that the opening and closing of CFTR channel gates are linked to ATP binding and hydrolysis at two nucleotide binding domains on the channel protein (NBD1 and NBD2) [32-35], and that the binding of AMP-PNP to one NBD specifically keeps the opening of the channels for a very long time (as if they were "locked open"). It is possible that a similar mechanism operated in the slow current deactivation observed in the present study. On the other hand, $\mathrm{UTP}_{\mathrm{o}}$ could hardly induce the $\mathrm{Cl}^{-}$current when the cells were dialyzed with only AMP-PNP or ATPS without ATP. This finding was taken to indicate that ATP hydrolysis is a prerequisite for the current activation. In line with this, it has been proposed that ATP hydrolysis at one NBD controls the opening of the CFTR $\mathrm{Cl}^{-}$channels [32-35].

Nucleotides are known to exert various electrophysiological and mechanical effects on heart, and some of these effects have been attributed to the stimulation of P2Y receptors $[1,2]$, but the receptor subtype responsible for each cardiac response induced by $\mathrm{P} 2 \mathrm{Y}$ receptor stimulation has not necessarily been clear. Our results suggest that $\mathrm{P}_{2} \mathrm{Y}_{2}$ receptor stimulation induces a definite electrophysiological response in mouse ventricular cells. Very recently, $\mathrm{UTP}_{\mathrm{o}}$ has been shown to exert a positive inotropic effect on mouse heart via $\mathrm{P} 2 \mathrm{Y}_{2}$ receptors [24]. It is interesting that $\mathrm{P} 2 \mathrm{Y}_{2}$ receptor mRNA levels in the left ventricle of rats were increased 4.7 fold under congestive heart failure, compared with control [36], suggesting a pathophysiological role of $\mathrm{P}_{2} \mathrm{Y}_{2}$ receptor in the development of heart failure.

UTP could be a physiologically important modulator of cardiac ionic currents. UTP ${ }_{0}$ has been reported to affect ATP-sensitive potassium current [18], sodium current [19], and muscarinic potassium channels [20] in heart. Our study demonstrates that $\mathrm{UTP}_{\mathrm{o}}$ activates a cardiac $\mathrm{Cl}^{-}$ current. The involvement of $\mathrm{Cl}^{-}$currents in the regulation of cardiac cell volume has been given attention, and an activation of the $\mathrm{Cl}^{-}$currents is expected to shrink the cell $[37,38]$. Under some pathological conditions, ischemia, for example, an osmotic stress induced by the intracellular accumulation of metabolites such as lactate may cause 
swelling of cardiac cells [39]. On the other hand, UTP has been reported to be released from cardiac cells under certain pathological conditions. The release of UTP was increased in rat cardiac hypertrophy [8], in rat hyperthyroid heart [9], and in pig cardiac ischemia [10]. Therefore the released UTP might exert a beneficial effect on cardiac muscle under such pathological conditions, playing a cell volume-regulatory role. Although UTP as an agonist may largely mimic the action of ATP on cardiac function, further studies are necessary to elucidate the physiological as well as the pathophysiological roles of UTP in the regulation of cardiac function.

This research was partly supported by Grants-in-Aid from the Ministry of Education, Science, Sports and Culture (No. 17500276 to T.E., and Nos. 16790138 and 18790158 to S.Y.), the 2004 COE program at the Saga University Faculty of Medicine (No. 27, 2004, to S.Y.), and the 2005 Young Medical Researcher Grants at the Saga University Faculty of Medicine (No. 1104081026 to T.E. and S.Y.).

\section{REFERENCES}

1. Vassort G. Adenosine 5'-triphosphate: a P2-purinergic agonist in the myocardium. Physiol Rev. 2001;81:767-806.

2. Burnstock $G$. Pathophysiology and therapeutic potential of purinergic signaling. Pharmacol Rev. 2006;58:58-86.

3. Communi D, Janssens R, Suarez-Huerta N, Robaye B, Boeynaems JM. Advances in signalling by extracellular nucleotides. the role and transduction mechanisms of P2Y receptors. Cell Signal. 2000;12:351-60.

4. Kunapuli SP, Daniel JL. P2 receptor subtypes in the cardiovascular system. Biochem J. 1998;336:513-23.

5. Ralevic V, Burnstock $G$. Receptors for purines and pyrimidines. Pharmacol Rev. 1998;50:413-92.

6. Lazarowski ER, Boucher RC, Harden TK. Mechanisms of release of nucleotides and integration of their action as $\mathrm{P} 2 \mathrm{X}$ - and $\mathrm{P} 2 \mathrm{Y}$-receptor activating molecules. Mol Pharmacol. 2003;64:785-95.

7. von Kügelgen I. Pharmacological profiles of cloned mammalian P2Y-receptor subtypes. Pharmacol Ther. 2005:doi:10.1016/j.pharmthera.2005.08.014.

8. Rossi A, Olivares J, Aussedat J, Ray A. Increased uracil nucleotide metabolism during the induction of cardiac hypertrophy by $\beta$-stimulation in rats. Basic Res Cardiol. 1980;75:139-42.

9. Hohl CM, Wetzel S, Fertel RH, Wimsatt DK, Brierley GP, Altschuld RA. Hyperthyroid adult rat cardiomyocytes. I. Nucleotide content, $\beta$ - and $\alpha$ adrenoreceptors, and cAMP production. Am J Physiol Cell Physiol. 1989;257:C948-56.

10. Erlinge D, Harnek J, van Heusden C, Olivecrona G, Jern S, Lazarowski E. Uridine triphosphate (UTP) is released during cardiac ischemia. Int $\mathrm{J}$ Cardiol. 2005:100:427-33.

11. Matsuura $\mathrm{H}$, Ehara $\mathrm{T}$. Activation of chloride current by purinergic stimulation in guinea pig heart cells. Circ Res. 1992;70:851-5.

12. Kaneda M, Fukui K, Doi K. Activation of chloride current by P2-purinoceptors in rat ventricular myocytes. Br J Pharmacol. 1994;111:1355-60.

13. Levesque PC, Hume JR. ATP ${ }_{0}$ but not CAMP $_{i}$ activates a chloride conductance in mouse ventricular myocytes. Cardiovasc Res. 1995;29:336-43.

14. Duan D, Ye L, Britton F, Miller LJ, Yamazaki J, Horowitz B, Hume JR. Purinoceptor-coupled $\mathrm{Cl}^{-}$channels in mouse heart: a novel, alternative pathway for CFTR regulation. J Physiol. 1999;521:43-56.

15. Yamamoto-Mizuma S, Wang GX, Hume JR. P2Y purinergic receptor regulation of CFTR chloride channels in mouse cardiac myocytes. J Physiol. 2004;556:72737.

16. Lin X, Jo H, Sakakibara Y, Tambara K, Kim B, Komeda M, Matsuoka S. $\beta$ adrenergic stimulation does not activate $\mathrm{Na}^{+} / \mathrm{Ca}^{2+}$ exchange current in guinea pig, mouse, and rat ventricular myocytes. Am J Physiol Cell Physiol.
2006;290:C601-8.

17. Yamamoto-Mizuma S, Wang GX, Liu LL, Schegg K, Hatton WJ, Duan D, Horowitz TL, Lamb FS, Hume JR. Altered properties of volume-sensitive osmolyte and anion channels (VSOACs) and membrane protein expression in cardiac and smooth muscle myocytes from $\mathrm{Clcn}^{-1-}$ mice. J Physiol. 2004:557:439-56.

18. Babenko AP, Vassort G. Purinergic facilitation of ATP-sensitive potassium current in rat ventricular myocytes. Br J Pharmacol. 1997;120:631-8.

19. Scamps $F$, Vassort $G$. Effect of extracellular ATP on the $\mathrm{Na}^{+}$current in rat ventricular myocytes. Circ Res. 1994;74:710-7.

20. Wu SN, Liu SI, Hwang TL. Activation of muscarinic $\mathrm{K}^{+}$channels by extracellular ATP and UTP in rat atrial myocytes. J Cardiovasc Pharmacol. 1998;31:203-11.

21. Webb TE, Barnard EA. Molecular biology of $P 2 Y$ receptors expressed in the nervous system. Prog Brain Res. 1999;120:23-31.

22. Banfi C, Ferrario S, De Vincenti O, Ceruti S, Fumagalli M, Mazzola A, N DA, Volonte C, Fratto P, Vitali E, Burnstock G, Beltrami E, Parolari A, Polvani G, Biglioli P, Tremoli E, Abbracchio MP. P2 receptors in human heart: upregulation of $\mathrm{P} 2 \mathrm{X}_{6}$ in patients undergoing heart transplantation, interaction with TNF $\alpha$ and potential role in myocardial cell death. J Mol Cell Cardiol. 2005;39:929-39.

23. Balogh J, Wihlborg AK, Isackson H, Joshi BV, Jacobson KA, Arner A, Erlinge D. Phospholipase $C$ and CAMP-dependent positive inotropic effects of ATP in

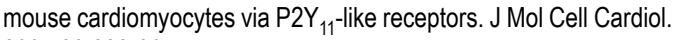
2005;39:223-30.

24. Wihlborg AK, Balogh J, Wang L, Borna C, Dou Y, Joshi BV, Lazarowski E, Jacobson KA, Arner A, Erlinge D. Positive inotropic effects by uridine triphosphate (UTP) and uridine diphosphate (UDP) via $\mathrm{P}_{2} \mathrm{Y}_{2}$ and $\mathrm{P} 2 \mathrm{Y}_{6}$ receptors on cardiomyocytes and release of UTP in man during myocardial infarction. Circ Res. 2006:98:970-6.

25. Zambon AC, Brunton LL, Barrett KE, Hughes RJ, Torres B, Insel PA. Cloning, expression, signaling mechanisms, and membrane targeting of $P 2 Y_{11}$ receptors in Madin Darby canine kidney cells. Mol Pharmacol. 2001;60:26-35.

26. Yamamoto S, Ehara T. Activation of cardiac chloride current by $P 2 Y_{2}$ receptor. Biophys J. 2005;88(1):255a.

27. Bannister RA, Melliti K, Adams BA. Reconstituted slow muscarinic inhibition of neuronal $\left(\mathrm{Ca}_{v} 1.2 \mathrm{C}\right) \mathrm{L}$-type $\mathrm{Ca}^{2+}$ channels. Biophys J. 2002;83:3256-67.

28. Hume JR, Duan D, Collier ML, Yamazaki J, Horowitz B. Anion transport in heart. Physiol Rev. 2000;80:31-81.

29. Vandenberg JI, Yoshida A, Kirk K, Powell T. Swelling-activated and isoprenalineactivated chloride currents in guinea pig cardiac myocytes have distinct electrophysiology and pharmacology. J Gen Physiol. 1994;104:997-1017.

30. North RA. Molecular physiology of P2X receptors. Physiol Rev. 2002;82:101367.

31. Ma T, Thiagarajah JR, Yang H, Sonawane ND, Folli C, Galietta LJ, Verkman AS. Thiazolidinone CFTR inhibitor identified by high-throughput screening blocks cholera toxin-induced intestinal fluid secretion. J Clin Invest. 2002;110:1651-8.

32. Gadsby DC, Nairn AC. Control of CFTR channel gating by phosphorylation and nucleotide hydrolysis. Physiol Rev. 1999;79:S77-S107.

33. Hwang TC, Nagel G, Nairn AC, Gadsby DC. Regulation of the gating of cystic fibrosis transmembrane conductance regulator $\mathrm{Cl}$ channels by phosphorylation and ATP hydrolysis. Proc Natl Acad Sci U S A. 1994;91:4698-702.

34. Nagel G. Differential function of the two nucleotide binding domains on cystic fibrosis transmembrane conductance regulator. Biochim Biophys Acta. 1999;1461:263-74.

35. Vergani P, Lockless SW, Nairn AC, Gadsby DC. CFTR channel opening by ATPdriven tight dimerization of its nucleotide-binding domains. Nature. 2005;433:876-80

36. Hou M, Malmsjo M, Moller S, Pantev E, Bergdahl A, Zhao XH, Sun XY, Hedner $T$, Edvinsson L, Erlinge D. Increase in cardiac P2X $\mathrm{X}_{1}$-and $\mathrm{P} 2 \mathrm{Y}_{2}$-receptor mRNA levels in congestive heart failure. Life Sci. 1999;65:1195-206.

37. Yamamoto S, Ehara T, Shioya T. Changes in cell volume induced by activation of the cyclic AMP-dependent chloride channel in guinea-pig cardiac myocytes. Jpn J Physiol. 2001;51:31-41.

38. Yamamoto S, Ishihara K, Ehara T, Shioya T. Cell-volume regulation by swellingactivated chloride current in guinea-pig ventricular myocytes. Jpn J Physiol. 2004:54:31-8.

39. Wright AR, Rees SA. Cardiac cell volume: crystal clear or murky waters? A comparison with other cell types. Pharmacol Ther. 1998;80:89-121. 